\title{
The Anti-inflammatory Effect and DPPH Free Radical Scavenging Capability of Rhizoma drynariae Aqueous Extract
}

\author{
Yong-Min Kim ${ }^{1}$, Ee-Hwa Kim² \\ ${ }^{1}$ Department of Oriental Medical and Herbal Cosmetic Sciences, Semyung University, \\ ${ }^{2}$ Department of Meridian \& Acupoint, College of Korean Medicine, Semyung University

\section{골쇄보 열수추출물 약침액의 항염증반응 및 $\mathrm{DPPH}$ 라디칼 소거능 활성에 대한 연구} \\ 김용민 $^{1} \cdot$ 김이화 $^{2}$ \\ ${ }^{1}$ 세명대학교 한방화장품과학과, ${ }^{2}$ 세명대학교 한의과대학 경락경혈학교실
}

\begin{abstract}
Objectives : This study is to investigate the effects of Rhizoma drynariae aqueous extract(RDA) on cell cytotoxicity, Nitric Oxide (NO) and Prostaglandin $\mathrm{E}_{2}\left(\mathrm{PGE}_{2}\right)$ production and 1,1-diphenyl-2-picryl ghdrazyl(DPPH) free radical scavenging capability. Methods : Cell cytotoxicity was measured by 3-(4,5-dimethylthiazol-2-yl)-2,5-diphenyltetrazolium bromide(MTT) assay. The production of $\mathrm{NO}$ was measured by Griess assay. The production of $\mathrm{PGE}_{2}$ was measured by immunoassay. And, the anti-oxidant activity was measured by the DPPH method. Results : Cell cytotoxicity in 50, 100, 200 and $400 \mu \mathrm{g} / \mathrm{ml} \mathrm{RDA}$ did not increase significantly compared to the RDA untreated group. $\mathrm{RDA}(200 \mu \mathrm{g} / \mathrm{ml}$ and $400 \mu \mathrm{g} / \mathrm{ml})$ inhibited $\mathrm{NO}$ and $\mathrm{PGE}_{2}$ production in lipopolysaccharide-stimulated RAW 264.7 cells. RDA had high DPPH free radical scavenging capability. Conclusions : This study indicates that $\mathrm{RDA}$ inhibits $\mathrm{NO}$ and $\mathrm{PGE}_{2}$ production in lipopolysaccharide-stimulated RAW 264.7 cells and improve DPPH free radical scavenging capability. RDA may have an anti-inflammation effect and an anti-oxidant activity.
\end{abstract}

Key words : anti-inflammation, anti-oxidant activity, Nitric Oxide, Prostaglandin E2, Rhizoma drynariae

\section{Introduction}

Inflammation is a local, protective response of the immune system. Excessive inflammatory responses can be harmful, as in diseases such as rheumatoid arthritis, Alzheimer's disease and septic shock syndrome ${ }^{1)}$. Lipopolysaccharide(LPS), a component of the cell wall of Gram-negative bacteria, stimulates macrophages to produce pro-inflammatory mediators such as tumor necrosis factor alpha, interleukin-6, and inducible nitric oxide synthase, which trigger a cascade responsible for the inflammatory response ${ }^{2)}$.

Of these, nitric oxide(NO) is endogenously generated from L-arginine by nitric oxide synthase(NOS) and plays an important role in the regulation of many physiological processes ${ }^{3)}$. In addition, prostaglandins(PGs) are key inflammatory mediator, converted from arachidonic acid by cyclooxygenase $e^{4)}$. Antioxidants can protect against the damage caused by free radicals that have been implicated in the etiology of large

Received November 24, 2015, Revised December 10, 2015, Accepted December 14, 2015

Corresponding author: Ee-Hwa Kim

Department of Meridian \& Acupoint, College of Korean Medicine, Semyung University, 65 Semyung-ro, Jecheon 27136, Korea

Tel: +82-43-649-1348, Fax: +82-43-649-1702, E-mail: kimeh@semyung.ac.kr

This paper was supported by the Semyung University Research Grant of 2013.

(c) This is an open access article distributed under the terms of the Creative Commons Attribution Non-Commercial License (http://creativecommons.org/licenses/ by-nc/4.0) which permits unrestricted non-commercial use, distribution, and reproduction in any medium, provided the original work is properly cited. 
number of major diseases(arterosclerosis, cancer, cardiac diseases, aging, brain diseases etc. $)^{5}$.

Rhizoma drynariae( $R$. drynariae) is made from the dried roots of Drynaria fortunei of the polypodicea family. It is bitter taste, providing inner warmth, and has meridian tropism for the liver and kidney. It can tone the kidney, improve blood circulation, reduce bleeding, and mediate injury healing. It is consistently used in the clinical treatment of kidney disease and bone injury ${ }^{6}$. There are many reports of modern pharmacological research on $R$. drynariae, mainly focusing on the treatment of bone disorders and fractures ${ }^{7,8)}$. $R$. drynariae is also known to be effective for the treatment of inflammation, hyperlipidemia, arteriosclerosis, rheumatism, and gynecological diseases such as osteoporosis and bone resorption in oriental medicine"). Liu et $\mathrm{al}^{10)}$ have also shown that $R$. drynariae has an antioxidant effect on rat osteoblasts from hydrongen peroxide-induced death.

Although many studies have been proviously reported about the medical effects of $R$. drynariae, the mechanism of the anti-inflammatory responses and anti-oxidant effects has not been elucidated. In this study, we investigated the anti-inflammatory and the anti-oxidant effects of $R$. drynariae using by 3-(4,5-dimethylthiazol-2-yl)-2,5-diphenyltetrazolium bromide(MTT) assay, nitric oxide(NO) and prostaglandin $\mathrm{E}_{2}\left(\mathrm{PGE}_{2}\right)$ production and 1,1-diphenyl-2-picryl ghdrazyl (DPPH) assay.

\section{Materials and Methods}

\section{Cell culture}

Cells of the murine macrophage RAW 264.7 were purchased from the Korean Cell Line Bank(KCLB, Seoul, Korea). Cells were cultured in Dulbecco's Modified Eagle Medium(DMEM)(Gibco BRL, Grand Island, NY, USA) supplemented with $10 \%$ heat-inactivated fetal bovine serum(FBS) (Gibco BRL) at $37^{\circ} \mathrm{C}$ in $5 \% \mathrm{CO}_{2}, 95 \% \mathrm{O}_{2}$ in a humidified cell incubator. Cells were plated in culture dish (Corning Incorporated, Corning, NY, USA) at a density of $1 \times 10^{6}$ cells per dish, and the media was changed once every 2 days.

\section{Preparation of extract}

To obtain the water extract of $R$. drynariae, $200 \mathrm{~g}$ of $R$. drynariae was added to distilled water, and extraction was performed by heating at $80^{\circ} \mathrm{C}$ concentrated with a rotary evaporator and lyophilized. The resulting powder, weighing $30 \mathrm{~g}$, was dissolved in saline.

\section{MTT cytotoxicity assay}

Cell viability was determined by the MTT assay kit using as per the manufactures protocol. Cells were cultured in 96 well plates. Experimental groups are exposed to $R$. drynariae aqueous extract(RDA) at final concentrations of 50, 100, 200 and $400 \mu \mathrm{g} / \mathrm{ml}$ for $24 \mathrm{hrs}$, and saline of an equal volume was added to untreated group. Ten ml of the MTT labeling reagent was then added to each well, and the plates were incubated for $4 \mathrm{hrs}$. After the cells were incubated in $100 \mathrm{ml}$ of the solubilization solution for $12 \mathrm{hrs}$, the absorbance was measured with a microtiter plate reader(Bio-Tek, Winooski, VT, USA) at a test wavelength of $595 \mathrm{~nm}$ with a reference wavelength of $690 \mathrm{~nm}$. The optical density(O.D.) was calculated as the result of the subtraction of the absorbance at the reference wavelength from that of the test wavelength. Percent viability was calculated as(O.D. of drug-treated sample/control O.D. $) \times 100$.

\section{NO assay}

The concentration of $\mathrm{NO}$ in the culture supernatants was determined by measuring nitrite, a major stable product of NO, using the Griess reagent. Briefly, Cells were plated onto 24-well plates and pretreated with the various concentrations of RDA $1 \mathrm{hr}$ prior to stimulation with $1 \mu \mathrm{g} / \mathrm{ml}$ of LPS for 24 hrs. Supernatant samples were mixed with equal volume of Griess reagent(1\% sulfanilamide and $0.1 \%$ naphthylethylenediamine dihydrochloride in 5\% phosphoric acid) and the incubated at room temperature for $10 \mathrm{~min}$. The absorbance was measured at $540 \mathrm{~nm}$ on a microplate reader (Thermo electron corporation, Marietta, $\mathrm{OH}$ ).

\section{Measurement of $P \mathrm{PE}_{2}$}

Enzyme-linked immunosorbent assay(ELISA) kit(R\&D Systems, 
Minneapolis, MN, USA) was used to measure $\mathrm{PGE}_{2}$ production according to the manufacturer's instructions. Cells were plated in 24-well plates and pretreated with the indicated concentrations of RDA $1 \mathrm{hr}$ prior to stimulation with $1 \mu \mathrm{g} / \mathrm{ml}$ LPS for $24 \mathrm{hrs}$. One hundred microliters of culture media were collected for the determination of $\mathrm{PGE}_{2}$ concentrations by ELISA according to the manufacturer's instructions.

\section{Assessment of DPPH radical scavenging activity}

The DPPH radical scavenging activity was measured according to previous studies ${ }^{11)}$ with a few modifications. Briefly, $2 \mathrm{~mL}$ of $0.2 \mathrm{mM}$ methanolic solution of DPPH radicals were added to $2 \mathrm{~mL}$ of water-solution of $\mathrm{RDA}$ at various concentrations. The absorbance of the mixture was measured at $517 \mathrm{~nm}$ after $30 \mathrm{~min}$ of incubation at $37^{\circ} \mathrm{C}$ in the dark. Ascobic acid was used as the control and distilled water as the blank. The scavenging effect was calculated according to the following equation: Scavenging rate $\%=\left(1-A_{s} / A_{0}\right) \times 100 \%$, where $A_{s}$ is the absorbance obtained for a sample and $A_{0}$, the absorbance of the blank.

\section{Statistical analysis}

Statistical analysis was performed using Student's t-test (SPSS 11.0 software) and the results were expressed as mean \pm S.E.M. Differences were considered significant for $p<0.05$.

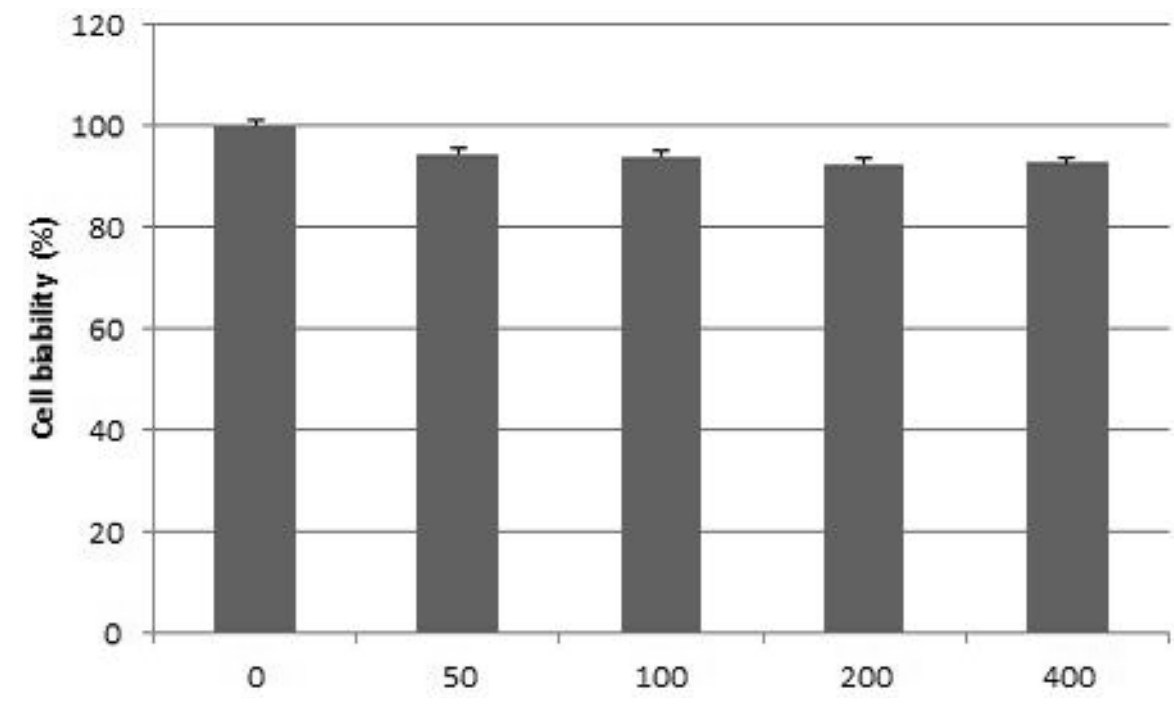

Fig. 1. Cytotoxic effects of Rhizoma drynariae aqueous extract(RDA). RAW 264.7 cells were incubated with RDA at various concentrations $(0,50,100,200$ and $400 \mu \mathrm{g} / \mathrm{ml})$ prior to the determination of cellular viability through MTT assay. Results were represented as mean \pm standard error. 
and $400 \mu \mathrm{g} / \mathrm{ml}$ were $13.52 \pm 0.83 \%, 97.60 \pm 5.30 \%, 94.85 \pm$ $5.46 \%, 76.28 \pm 4.88 \%$ and $66.42 \pm 5.23 \%$ of the control value $(100 \pm 5.06 \%)$ respectively. RDA significantly inhibited NO production at concentrations of $200 \mu \mathrm{g} / \mathrm{ml}$ and $400 \mu \mathrm{g} / \mathrm{ml}$ (Fig. 2).

\section{Measurement of $\mathrm{PGE}_{2}$ production}

To determine the effects of $\mathrm{RDA}$ on $\mathrm{PGE}_{2}$ production in RAW 264.7 cells, the cells were pre-incubated with various concentrations of RDA for $1 \mathrm{hr}$ and then stimulated with $1 \mu \mathrm{g} / \mathrm{ml}$ of LPS for $24 \mathrm{hrs}$. The control group was not treated with LPS or RDA. Supernatant from cell culture media was collected, and $\mathrm{PGE}_{2}$ levels were determined with the EIA kit. $\mathrm{RDA}$ was found to inhibit LPS-induced $\mathrm{PGE}_{2}$ productions in a dose-dependent manner. The $\mathrm{PGE}_{2}$ production of $\mathrm{RDA}$ at concentrations of $0 \mu \mathrm{g} / \mathrm{ml}, 50 \mu \mathrm{g} / \mathrm{ml}, 100 \mu \mathrm{g} / \mathrm{ml}, 200 \mu \mathrm{g} / \mathrm{ml}$ and $400 \mu \mathrm{g} / \mathrm{ml}$ were $4.70 \pm 0.64 \%, 100.96 \pm 5.82 \%, 98.36 \pm$ $7.31 \%, 84.88 \pm 3.76 \%$ and $82.55 \pm 6.06 \%$ of the control value $(100.00 \pm 6.56 \%)$ respectively. RDA significantly inhibited $\mathrm{PGE}_{2}$ production at concentrations of at $200 \mu \mathrm{g} / \mathrm{ml}$ and $400 \mu \mathrm{g} / \mathrm{ml}$ (Fig. 3).

\section{Measurement of DPPH radical scavenging activity}

Scavenging of DPPH radicals is the basis of a common antioxidant assay. Antioxidants can protect against the damage caused by free radicals that have been implicated in the etiology of large number of major diseases. RDA displayed concentration dependent radical scavenging effects. RDA were $4.76 \pm 1.88 \%, 24.43 \pm 3.14 \%, 61.86 \pm 2.15 \%$ and $77.03 \pm$ $4.64 \%$ at concentrations of $50 \mu \mathrm{g} / \mathrm{ml}, 100 \mu \mathrm{g} / \mathrm{ml}, 200 \mu \mathrm{g} / \mathrm{ml}$ and $400 \mu \mathrm{g} / \mathrm{ml}$ (Fig. 4).

\section{Discussion}

The purpose of this study is to investigate the effects of $\mathrm{RDA}$ on the production of $\mathrm{NO}$ and $\mathrm{PGE}_{2}$ induced by LPS-stimulated RAW 264.7 cells and DPPH free radical scavenging capability.

Inflammation is a complex process regulated by a variety of immune cells and effector molecules. NO, $\mathrm{PGE}_{2}$, and pro-inflammatory cytokines are important mediators of macrophage-mediated inflammation ${ }^{12,13)}$. Therefore, the inhibition of these mediators with pharmacological modulators may be an effective therapeutic strategy for preventing inflammatory reactions and diseases ${ }^{14)}$.

Macrophages play critical roles in immune reactions, allergy, and inflammation ${ }^{15)}$. These cells induce inflammatory reactions, and initiate and maintain specific immune responses by releasing different types of cytokines. LPS, a comonent of the gram-negative bacterial cell wall, has often been used in inflammatory response because it can activate

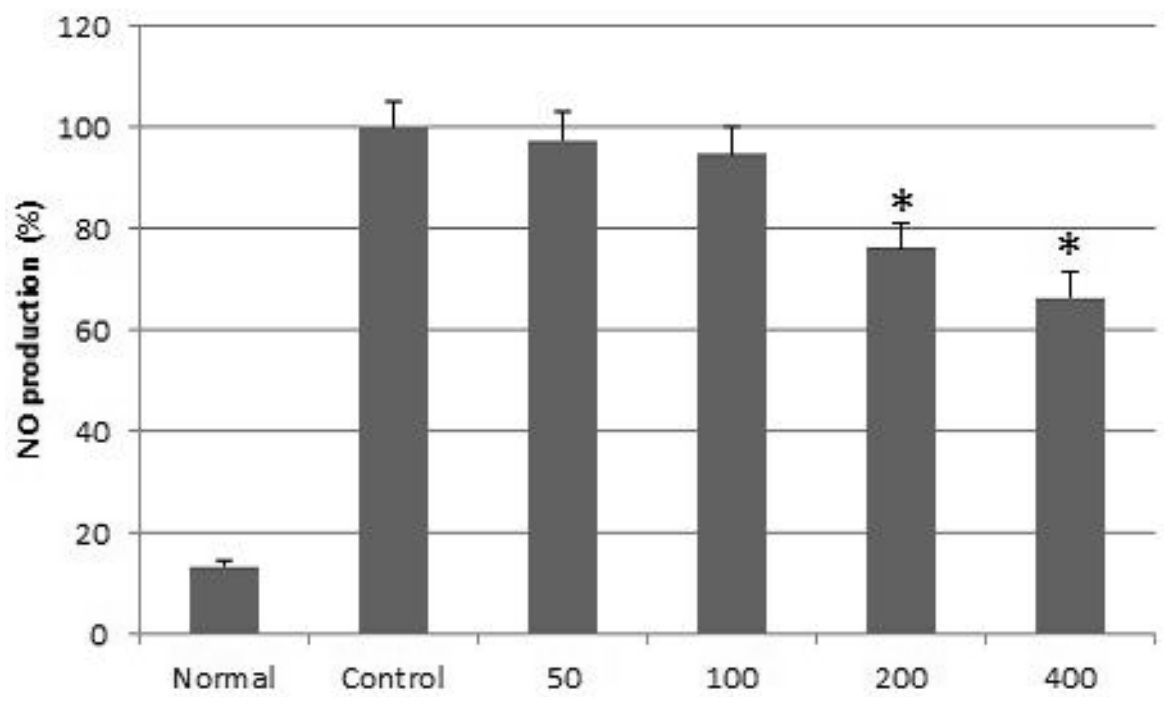

Fig. 2. Effects of Rhizoma drynariae aqueos extract(RDA) on the nitric oxide(NO) production in RAW 264.7 cells.

Normal, untreated group : Control, treated with LPS $(1 \mu \mathrm{g} / \mathrm{ml}) ; 50 \sim 400$, treated with LPS and RDA(50 400 $\mu \mathrm{g} / \mathrm{ml})$. *represents $p<0.05 \mathrm{com}-$ pared to the Control group. 
macrophages ${ }^{16)}$.

In general, NO plays an important role in the antitumour, antivirus replication and other diseases ${ }^{17,18)}$, the overproduction of NO is harmful to the host, leading to rheumatoid arthritis $^{19)}$ and allograft rejection ${ }^{20)}$. NO production from macrophages can be induced by inflammatory cytokines or bacterial products, including LPS, IFN-gamma, or TNFalpha $^{21)}$.

$\mathrm{PGE}_{2}$ is considered the one of the strongest inflammatory mediators in inflammatory response. It was transformed from arachidonic acid via the cyclooxygenase-2 (COX-2) catalytic reaction. Nonsteroidal anti-inflammatory drugs (NSAIDs), which were used widely in current clinical, play their antipyretic, anti-inflammatory and analgesic effects through the inhibition of COX activity and the reduction of inflammatory mediator production such as $\mathrm{PGE}_{2}{ }^{22)}$.

Oxidative stress is an important factor in the genesis of most pathologies, ranging from cancer to cardiovascular and degenerative diseases ${ }^{23}$. In order to protect the body against the consequences of oxidative stress, an efficacious approach consists in improving the anti-oxidant nutrition. Anti-oxidants from natural sources have a higher bioavailability and therefore higher protective efficacy than synthetic antioxidants $^{24)}$.
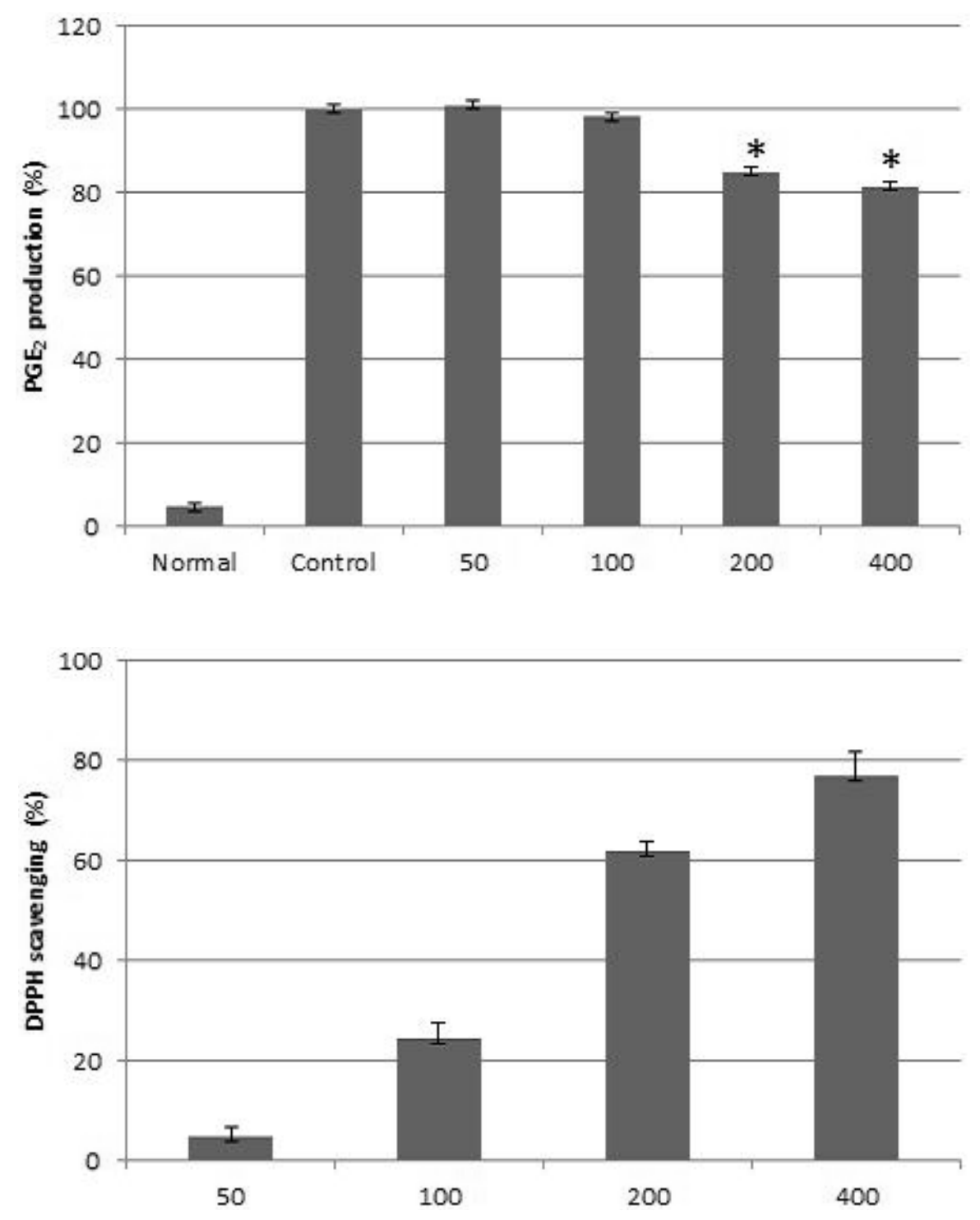

Fig. 3. Effects of Rhizoma drynariae aqueos extract(RDA) on the prostaglandin $E_{2}\left(P_{G} E_{2}\right)$ production in RAW 264.7 cells.

Normal, untreated group ; Control, treated with LPS $(1 \mu \mathrm{g} / \mathrm{ml}) ; 50 \sim 400$, treated with LPS and RDA $(50 \sim 400$ $\mu \mathrm{g} / \mathrm{ml})$. *represents $p<0.05 \mathrm{com}-$ pared to the Control group.

Fig. 4. DPPH free radical scavenging capability of Rhizoma drynariae aqueos extract(RDA).

The absorbance of the RDA (50 $400 \mu \mathrm{g} / \mathrm{ml}$ ) was measured at 517 $\mathrm{nm}$. Results were represented as mean \pm standard error. 
Free radicals are chemical species with one or two unpaired electrons in their outermost layer, which can be created in a multiple ways. They can be exogenic(e.g. ultraviolet radiation, pollution, infections, tobacco) or endogenic. A lack of anti-oxidant or an overproduction in free radicals cab lead to an imbalance between the oxidant and anti-oxidant system. One of the most significant factors in the production of free radicals is oxidative stress ${ }^{25-28}$. Oxidative stress is involved in a several illnesses, including diabetes ${ }^{29,30)}$, atherosclereosis, Alzheimer's disease, Parkinson's disease, glaucoma and age-related macular degeneration ${ }^{31,32}$. The provision of anti-oxidants through diet or herb-medicine is a simple means to reduce the development of illnesses brought on by oxidative stress ${ }^{33,34)}$.

RDA has effects on reinforcing kidney, improving circulation, reduce bleeding, air wound healing, etc. In the clinical setting, RDA is consistently used for the treatment of kidney dysfunction as well as traumatic fractures. In the ancient monographs of orthopedics and traumatology, RDA had a very high frequency of prescription. Under these influences, modern pharmacological studies mainly focus on the treatment of bone fractures and bone diseases ${ }^{35,36}$. Lee et $\mathrm{al}^{377}$ reported that $\mathrm{RDA}$ inhibited proliferation of mitogen (phytohaemagglutinin) and antigen(purified protein derivative)-stimulated human peripheral blood mononuclear cells. In addition, RDA inhibited growth of several cell lines of mouse and human origin. Current Korean Medical treatments are not only confined to acupuncture, moxibustion, and herbal medication. Rather, various other treatments have been developed and are already being used clinically ${ }^{38)}$. Therefore, it may be useful for the development of aquaacupuncture.

Currently, there are few reports on the effects of RDA on the inflammatory disease. In our study, we investigated that $\mathrm{RDA}$ inhibits the production of $\mathrm{NO}$ and $\mathrm{PGE}_{2}$ induced by LPS-stimulated RAW 264.7 cells and improve DPPH free radical scavenging capability. RDA may have an antiinflammation effect and anti-oxidant activity. Therefore, we believe that RDA may be useful for the patients with several inflammation diseases.

\section{Acknowledgement}

This paper was supported by the Semyung University Research Grant of 2013.

\section{References}

1. Tracey KJ. The inflammatory reflex. Nature. 2002 ; 420 : 853-859.

2. Chen X, Miao J, Wang H, Zhao F, Hu J, Gao P, Wang Y, Zhang L, Yan M. The anti-inflammatory activities of Ainsliaea fragrans Champ. extract and its components in lipopolysaccharidestimulated RAW264.7 macrophages through inhibition of NF-kB pathway. Journal of Ethnopharmacology. 2015 ; 170 : $72-80$.

3. Dawson TM, Dawson VL, Snyder SH. A novel neuronal messenger molecule in brain: the free radical, nitric oxide. Ann Neurol. 1992 ; 32(3) : 297-311.

4. Yui Y, Hattori R, Kosuga K, Eizawa H, Hiki K, Kawai C. Purification of nitric oxide synthase from rat macrophages. J Biol Chem. 1991 ; 266(19) : 12544-12547.

5. Devasagayam TPA, Tilak JC, Boloor KK, Sane KS, Ghaskadbi SS, Lele RD. Free radicals and antioxidants in human health: current status and future prospects. Journal of the Association of Physicians of India. 2004; $52:$ 794-804.

6. Wang W, Pan Y, Wei J, Huang L, Huang X, Li K. The effects of Rhizoma drynariae on interleukin-2 and T-lymphocyte levels in rats after severe head injury. Journal of Ethnophamacology. $2012 ; 142: 300-304$

7. Chen J, Zhou D, Zheng W. Impairment of cellular immunological function in comatose patients after brain injury. Journal of Traumatic surgery $2004 ; 6(3): 179-181$.

8. Peng Y, Tian L, Zeng S. Change and significance after severe brain injury. Capital Medicine. 2007 ; 7(14) : 37-38.

9. Shi XC, Chinese-English terminology of traditional Chinese medicine. China: Human Science Publishing. 1983 : 71-98.

10. Liu HC, Chen RM, Jian WC, Lin YL. Cytotoxic and antioxidant effects of the water extract of the traditional Chinse herb gusuibu on rat osteoblasts. J Formos Med Assoc 2001 ; 100 : 383-388. 
11. Wang H, Gao XD, Zhou CG, Cai L, Yao WB. In vitro and in vivo antioxidant activity of aqueous extract from Choerospondias axillaris fruit. Food Chemistry. $2008 ; 106: 888-895$.

12. Reed GA, Arneson DW, Putnam WC, Smith HJ, Gray JC, Sullivan DK, Mayo MS, Crowell JA, Hurwitz A. Single-dose and multiple-dose administration of indole-3-carbinol to women: pharmacokinetics based on 3,3'-diindolymethane. Cancer Epidermiol. Biomarkers Prev. 2006 ; 15 : 2477-2481.

13. Rahman KW, Sarkar FH. Inhibition of nuclear translocation of nuclear factor-(kappa)B contributes to 3,3'-diindolymethaneinduced apoptosis in breast cancer cells. Carcer Res. $2005 ; 65$ :364-371.

14. Xia Z, Triffitt JT. A review on macrophage response to biomaterials. Biomed. Mater. $2006 ; 1: 1-9$.

15. Ross JA, Auger MJ, Burke B, Lewis CE. The biology of the macrophage. In:Burker B, Lewis CE (Eds.). The Macrophage, 2nd ed. Oxford Medical Publications, Oxford, UK, 2002 : 1-72.

16. Poltorak A, He X, Smirnova I, Liu MY, Van Huffel C, Du X, Birdwell D, Alejos E, Silva M, Galanos C, Freudenberg M, Ricciardi-Castagnoli P, Layton B, Beutler B. Defective LPS signaling in $\mathrm{C} 3 \mathrm{H} / \mathrm{Hej}$ and $\mathrm{C} 57 \mathrm{BL} / 10 \mathrm{ScCr}$ mice. Mutations in Tlr4 gene. Science. 1998 ; 282 : 2085-2088.

17. Schmidt HH, Walter U. NO at work. Cell. 1994 ; 78 : 919-925.

18. MacMicking J, Xie QW, Nathan C. Nitric oxide and macrophage function. Annual Review of Immunology. 1997 ; 15 : 323-350.

19. St Clair EW, Wilkinson WE, Lang T, Sanders L, Misukonis MA, Gilkeson GS, Pisetsky DS, Granger DI, Weinberg JB. Increased expression of blood mononuclear cell nitric oxide synthase type 2 in rheumatoid arthritis patients. Journal of Experimental Medicine. 1996; 184: 1173-1178.

20. Worrall NK, Lazenby WD, Misko TP, Lin TS, Rodi CP, Manning PT, Tilton RG, Williamson JR, Ferguson Jr. TB. Modulation of in vivo alloreactivity by inhibition of inducible nitric oxide synthase. Journal of Experimental Medicine. 1995 ; 181 : 63-70.

21. Chiou WF, Chou CJ, Chen CF. Camptothecin suppresses nitric oxide biosynthesis in RAW 264.7 macrophages. Life Sciences. $2001 ; 69: 625-635$.

22. Hu XD Yang Y, Zhong XG, Zhang XH, Zhang YN, Zheng ZP, Zhou Y, Tang W, Yang YF, Hu LH, Zuo JP. Anti-inflammatory effects of Z23 on LPS-induced inflammatory responses in
RAW264.7 macrophages. Journal of Ethnopharmacology. $2008 ; 120: 447-451$.

23. Parthasarathy S, Khan-Marchant N, Penumeteha M, Santanam N. Oxidative stress in cardiovascular disease. J Nuclear Cardiol. $2001 ; 8(3): 379-389$.

24. Benedetti S, Benvenah F, Pagharami S. Francegh S, Stephano S, Canestrari F. Antioxidant properties of a novel phycocyania extract from the blue-green alga Aphanizomenonflos-aquae. Life sci. $2004 ; 75: 2353-2362$.

25. Guerci B, Bohme P, Kearney-Schwartz A, Zannad F, Drouin P. Endothelial dysfunction and type 2 diabetes. Diabetes Metab. $2001 ; 27: 436-447$.

26. Punitha ISR, Rajendran K, Shirwaikar A, Shirwaikar A. Alcoholic stem extract of Coscinium fenestratum regulates carbohydrate methbolism and improves antioxidant status in streptozotocinnicotinamide induced diabetic rats. eCAM 2005 ; 2(3) : 375-381.

27. Zhao K, Luo G, Giannelli S, Szeto HH. Mitochondriatargeted peptide prevents mitochondrial depolarization and apoptose induced by tert-butyl hydroperoxide in neuronal cell lines. Biochem Pharmacol 2005; 70 : 1796-1806.

28. Long AC, Colitz CM, Bomser JA. Apoptotic and necrotic mechanisms of stress-induced human lens epithelial cell death. Exp Biol Med. 2004; 229 : 1072-1080.

29. Pincemail J. Meurisse M, Limet R, Defraigne JO. L'evaluation du stress oxydatif d'un individu : une realite pour le medecin. Vaisseaux Coeur Poumons 1999 ; 4(5) : 12-23.

30. Huang DJ, Lin CD, Chen HJ, Lin YH. Antioxidant and antiproliferative activities of sweet potato constituents. Bot Bull Acad Sin. $2004 ; 45:$ 179-186.

31. Drobek-Slowik M, Karezewicz DK. The potential role of oxidative stress in the pathogenesis of the age-related macular degeneration (AMD). Postepy Hig Med Dosw. 2007 ; 61 : 28-37.

32. Bonne $\mathrm{C}$, Muller A. Role of oxidative stress in age-related macular degeneration. J Fr Ophtalmol. 2000 ; 23 : 835-840.

33. Zafra-Stones S, Yasmin T, Bagchi M, Chattejee A, Vinson JA, Bagchi D. Berry anthocyanins as novel antioxidants in human health and disease prvention. Mol Nutr Food Res. 2007 ; 51 : 675-683.

34. Bagchi D, Bagchi M, Stohs SJ, Das DK, Ray SD, Kuszynski CA, 
Joshi SS, Pruess HG. Free radicals and grape seed proanthocyanidin extract : importance in human health and disease prevention. Toxicology. $2000 ; 148: 187-197$.

35. Tang Q, Chen L, Jie Y. Effects of traditional Chinese medicine Drynaria fortuneismith on promoting the proliferation, differentiation and calcification of mouse osteoblastic MC3T3-E1 cells. China Journal of Chinese Mareria Medica 2004 ; 29(2) : 64-168.

36. Liu H, Wang W. Experimental research on prevention of ste- roid-induced avascular necrosis of femoral head with injection of Salvia Miltiorrhiza and Drynaria. China Journal of Orthopaedics and Traumatology. 2003 ; 16(12) : 726-728.

37. Lee KU, Jeong JC. Immunomodulatory activities of ethanolic extract of Drynariae Rhizoma. Korean J Oriental Med. 2004 ; 25(1) : 16-27.

38. Seo HS. An experimantal study of the anti-oxidant and the anti-inflammatory effects of Alum and Burnt Alum. J pharmacopuncture. $2012 ; 15(2): 11-14$.

\section{국문초록}

목적 : 한의학에서 골절이나 신장질환에 사용되어 왔던 골쇄보열수추출물 약침액이 항염증 및 항산화활성에 대한 효능이 있는지를 연구하고 자 한다. 방법 : 골쇄보열수추출물 약침액이 세포독성에 미치는 영향을 관찰하기 위하여 3-(4,5-dimethylthiazol-2-yl)-2,5-diphenyltetrazolium bromide(MTT) assay를 실시하였다. 골쇄보열수추출물 약침액이 항염증효능에 미치는 영향을 관찰하기 위하여 lipopolysaccharide(LPS)로 유도된 RAW264.7 대식세포에서의 산화질소(NO) 및 프로스타글란딘(PGE $)$ 생성 억제력을 관찰하였다. 또한 골쇄 보열수추출물 약침액이 항산화활성에 미치는 영향을 관찰하기 위하여 1,1-diphenyl-2-pciry hydrazyl(DPPH) radical 소거능을 관찰하였 다. 결과 : 골쇄보열수추출물 약침액은 $50 ~ 400 \mu \mathrm{g} / \mathrm{ml}$ 농도에서 세포독성이 나타나지 않았다. 골쇄보열수추출물 약침액은 200 및 $400 \mu \mathrm{g} /$ $\mathrm{ml}$ 농도에서 $\mathrm{LPS}$ 로 유도된 $\mathrm{NO}$ 및 $\mathrm{PGE}_{2}$ 생성을 통계학적으로 유의하게 감소시켰다. 골쇄보추출물은 $50 \sim 400 \mu \mathrm{g} / \mathrm{ml}$ 농도에서 DPPH 소거 능을 관찰한 결과 농도의존적으로 활성화되는 것을 관찰하였다. 결론 : 골쇄보열수추출물 약침액은 항염증 및 항산화 효과가 있을 것으로 사 료된다. 